\title{
ВЛАСТЬ-СПЕЦЭФФЕКТ: ГЕНЕЗИС И ПОЛИТИКО-ИДЕОЛОГИЧЕСКАЯ МИССИЯ ВИЗУАЛЬНЫХ ТЕХНОЛОГИЙ В ТРАДИЦИИ АМЕРИКАНСКОГО ФИЛЬМА УЖАСОВ
}

\author{
Маленко Сергей Анатольевич, \\ olenia@mail.ru \\ Некита Андрей Григорьевич, \\ beresten@mail.ru
}

Новгородский государственный университет имени Ярослава Мудрого, Россия, 173003, Великий Новгород, ул. Большая Санкт-Петербургская, 41

\begin{abstract}
Маленко Сергей Анатольевич, доктор философских наук, профессор, заведующий кафедрой философии, культурологии и социологии Новгородского государственного университета имени Ярослава Мудрого.
\end{abstract}

Некита Андрей Григорьевич, доктор философских наук, профессор кафедры теории, истории и философии культуры Новгородского государственного университета имени Ярослава Мудрого.

Актуальность. Установление зависимости номенклатуры и характера художественных и технических приемов, применяемых в кинематографе, от социокультурного и политико-идеологического контекста представляет значимую научную проблему и позволяет сформировать новое, междисциплинарное предметное поле в современных культурологических исследованиях. Цель: проанализировать направленность эволюции визуальной и политической сущности кинематографических спецэффектов в контексте историко-культурных трансформаций западного общества в конце ХІХначале XXI вв., а также особенности их использования в традищии американских фильмов ужасов. Методы. В статье использован ряд методов, позволяющих осуществить компаративистский, семиотический и психоаналитический анализ сущности и художественной практики использования спецэффектов в голливудском кинематографе. Результаты. Формирование художественной практики американских фильмов ужасов напрямую связано с использованием технических приемов, позволяющих удерживать постоянный зрительский интерес к этой кинопродукции. Спецэффекты в различных киножанрах становятся результатом переосмысления опыта циркового, театрального и фотоискусства в процессе конструирования танатологической гиперреальности, вытесняющей образы предметного мира и замещающей их динамичными иллюзиями. Резкая эскалация применения этих технических приемов свидетельствует о появлении новых инструментальных возможностей создания и продвижения вторичной реальности. Непрерывно усугубляющийся разрыв между наличным и кинематографическим миром демонстрирует рост отчуждения публики от традиционных форм социальной практики, что обуславливает скачок симулятивных экспериментов в фильмах ужасов и всевозрастающий интерес власти к визуальным способам привлечения, удержания и бессознательного управления вниманием и поведением массового зрителя. Выводы. Спектр кинематографических спецэффектов создает визуальную технологию управления страхом, формирует особый хоррор-габитус, что представляет собой коммерчески прибыльную и наиболее востребованную политико-идеологическую задачу голливудского фильма ужасов.

Ключевые слова: Американские фильмы ужасов, власть-спецэффект, хоррор-габитус, гиперреальность, симуляция, визуализация, массовая культура.

Появление кинематографа и последующий подъем Голливуда как его важнейшего транснационального производственного предприятия были связаны с целым комплексом социокультурных, социально-политических и технологических изменений с кото- 
рыми столкнулась человеческая цивилизация на рубеже XIX-XX вв. Эти трансформации были настолько масштабными, комплексными и разительными, что нашли самый широкий отклик в среде мировой политической, технической, научноисследовательской и художественной интеллигенции. Как и выходцы из бизнес-элиты, ее лучшие представители во многих странах мира с разных сторон пытались осмыслить на глазах происходящие изменения, с тем чтобы максимально полезно и прибыльно включить их в контекст быстро меняющейся жизни. В политической сфере это во многом было связано с оценкой масштабов и колоссальных жертв Первой мировой войны, ставшей действительно первым военным конфликтом цивилизации в череде тысяч других, который нашел отражение в документальной видеохронике.

К тому же изобретение автомобиля, самолета, конвейера, танка, радио, первая апробация оружия массового поражения и других технических новинок продемонстрировали насущную потребность и в новом уровне промышленного и повседневного сопровождения обывательской жизни. Перед наукой того времени также стояли крайне непростые задачи, с одной стороны, связанные с необходимостью скорейшего включения хотя бы части катастрофических по скорости и масштабам изменений нескольких последних десятилетий на рубеже нового века в мировоззренческую картину безвозвратно изменившегося мира, а с другой - выражающиеся в отчаянном стремлении хоть както осмыслить факт окончательной смерти классической культуры и трагическое во всех отношениях крушение характерной для нее антропологической парадигмы. Художественный опыт рубежа столетий ознаменовался зарождением модернизма с его разнонаправленными стремлениями, с одной стороны, хоть как-то сохранить традиционные образно-символические горизонты мира, а с другой - очертить границы нового понимания человека в условиях существенных трансформаций его чувственнорациональных и интеллектуальных запросов и возникших новых возможностей их удовлетворения.

Изобретение фото- и кинокамеры, по сути, выступило той объединяющей новацией, которая смогла увязать все перечисленные выше сферы человеческой деятельности в единое визуальное целое. Масштабы и характер отклика, который тогда находили фотография и кино в официальной и повседневной жизни, мы можем полноценно понять только сегодня, в начале XXI в. Как раз сегодня за плечами у человечества есть более чем столетний промежуток, столь необходимый для отстраненной оценки масштабов и последствий динамической визуальной революции. Во многом она была связана с практически мгновенным (безо всякой исторической дистанции) вхождением кинематографа не только в официальную, но и в первую очередь в повседневную жизнь миллионов людей по всему миру. Ведь именно кинематограф интуитивно попытался визуализировать все наиболее острые и актуальные антропологические запросы, которые впервые в истории массово возникли только на рубеже Новейшего времени.

Практически повсеместные острейшие экономические и политические противоречия, приведшие к Первой мировой войне и череде социальных революций, лишь зафиксировали трагический уровень неудовлетворенности сотен тысяч людей по всему миру господствующим типом хозяйствования и порожденными им способами коммуникации. И это была даже не столько сама по себе констатация наличия социальных противоречий, сколько фиксация повсеместной разочарованности человека в сложившемся способе официальной и повседневной жизни. И если одна, меньшая часть человечества все ещё продолжала наивно верить, что только посредством прогрессивных, революционных преобразований можно придать новые позитивные качества устаревшим укладам общественной жизни, то его большая часть в отчаянном порыве попыта- 
лась бессознательно компенсировать небывалый уровень социального пессимизма и разочарованности, очертя голову, бросившись в безбрежное пространство визуального вымысла, для создания и продвижения которого модернистское искусство столь активно использовало технические и технологические новинки, подоспевшие как нельзя более удачно и вовремя.

Авторы уверены, что именно технологические новации придали модернистскому искусству вообще и кинематографу в частности невиданный ранее импульс компенсации разрушенного или так и не обретенного мира, сублимации вытесненных фантазийности и иллюзионизма, в пучине которых запросто могли «потеряться» или «провалиться» не только отдельные индивиды и социальные группы, разочаровавшиеся в социальном способе бытия, но и целые поколения, вдруг почувствовавшие себя «лишними» в этом новом, необычайно «безумном» и жестоком, прагматично-иррациональном мире. И в то время как одна часть человечества самоотверженно и возвышенно-наивно возложила свои жизни на алтарь борьбы за создание островка «горнего» мира в теснинах старого и прогнившего цивилизационного бытия, за вожделенное созидание оплота новой коммунитарности на руинах тысячелетней несправедливости и угнетения, его другая часть эту же самую задачу попыталась решить в форме кинематографического «удвоения» наличной реальности, ярко визуализирующего социальные идеалы первой группы и творчески сублимируя весь художественно-эстетический опыт предшествующей человеческой культуры.

Согласно более поздним постмодернистским трактовкам, кинематограф непрерывно производит симулякры, которые в равной степени представлены в палитре его жанрового многообразия. Поэтому симулякры и выступают неким метажанровым феноменом, который настойчиво пытается визуализировать наиболее актуальные культурные коды, непрерывно формирующиеся на фундаментальном противоречии между сущим и должным. В силу этого киносимулякры имеют исключительно положительную окраску, поскольку отвечают важнейшим экзистенциальным запросам зрителей, что дополнительно подтверждается непрерывно возрастающей популярностью этого самого массового жанра искусства. И действительно, кинематограф стал той желанной отдушиной, оказавшейся вожделенным эталоном чувств, мыслей, поступков, доступно и массово транслирующим символическое ощущение небывалого ранее коллективного единства, немыслимого ни в одном из реальных этно-национальных, социальноэкономических и политико-идеологических пространств. По мысли американского режиссера С. Люмета, кино - это «единственная форма искусства, использующая живых людей, чтобы запечатлеть нечто в буквальном смысле большее, чем сама жизнь. Это недоступно ни литературе, ни другим формам искусства» [1, с. 247].

В этом-то и состоит разгадка феномена массового искусства как такового, которое посредством производства и потребления культурных продуктов создает и тиражирует всеобщую иллюзию мифической, поистине вселенской сопричастности каждого созерцающего фильм зрителя. Один из авторов словаря «New keywords: a revised vocabulary of culture and society» John Storey считает, что современная «популярная культура - это коммерческая культура, массово производимая для массового потребления. Это культура, которая якобы поглощена примитивной и ограниченной пассивностью мозга. Его аудитория - это масса недискриминационных потребителей, потребляющих то, что шаблонно и манипулятивно (для политических правых или левых, в зависимости от того, кто делает анализ)» [2, с. 264].

Интуитивное понимание важности этих ожиданий массового потребителя изначально характеризовало становящийся американский кинематограф, в связи с чем рос- 
сийский исследователь Н. Никулин справедливо указывал, что Голливуд всегда питал слабость к мифическим темам, поскольку они всегда «масштабны, они кровавы, и, в конце концов, они просто зрелищны. Сколько бы жанр ни сковывал режиссеров, зрителям он, напротив, предоставляет шанс легко вздохнуть: не нужно вникать в авторскую мысль, жанр говорит сам за себя» [3, с. 216].

Необыкновенный и повсеместный успех кинематографа как раз и заключался в том, что он на короткий период времени погружал массового зрителя в визуализированный, игровой вымысел, который чудесным способом переносил его в пространство смонтированной динамической иллюзии, наиболее сообразной природе человеческой фантазийности, что позволяло актуализировать значимые образы взаимосвязей между людьми и окружающим миром. Эта черта только что возникшего вида искусства сразу же попала в поле зрение представителей власти, которые в тот кризисный период также были всерьез озабочены поисками эффективных механизмов управления «дивным, новым миром» и быстро смекнули, что в жестоких условиях конкурентных капиталистических отношений кинематографический конвейер - это, скорее всего, «не бурный поток фантазии, а наука сродни атомной физике» [3, с. 126], тогда как любая киностудия - «это всего лишь орудие в руках капитализма» [3, с. 151]. Эта же исключительная особенность политико-идеологического статуса кинематографа ложится и в основание его продвижения как самого популярного и иллюзорного жанра массовой культуры, который в смычке с технологичным производством практически мгновенно превратился в эффективный инструмент и мировой образец достижения наивысшего экономического успеха. Тот же С. Люмет констатировал факт, что именно кинофильмы со временем совершенно закономерно «стали жизненно необходимой частью огромных финансовых империй. И, похоже, эта тенденция со временем будет только расти» [1, с. 246].

Политический и идеологический шлейф сопровождал кинематограф уже с самого момента его возникновения, поэтому, как только эта технологическая диковинка завоевала внимание достаточного количества обывателей по всему миру, ей стали активно интересоваться и власть имущие. Так, в одной из бесед с народным комиссаром просвещения А. Луначарским, состоявшейся в феврале 1922 г., В. Ленин произнес недвусмысленную фразу, моментально вошедшую во все советские учебники истории: «Из всех искусств для нас важнейшим является кино» [4, с. 579]. Напомним, что это было сказано в тот период, когда Европа едва только начала залечивать глубокое раны, нанесенные Первой мировой войной, а классический европейский тоталитаризм еще даже не сложился. Позднее в письме Г. Болтянскому А. Луначарский указывает, что Ленин в его беседе с ним сформулировал задачу коммунистического кинематографа, состоящую в достижении «определенной пропорции между увлекательными кинокартинками и научными» [5, с. 16].

Специфическое понимание исключительной важности кинематографа в укреплении власти в переходной период о «старого» к «новому» миру присутствовало и у соратников вождя мирового пролетариата. Так, председатель Реввоенсовета СССР Л. Троцкий, который в своей известной статье «Водка, церковь и кинематограф», опубликованной в «Правде» - главной партийно-пропагандистской газете страны Советов от 12 июля 1923 г., прямо указывал, что желание «развлечься, рассеяться, поглазеть и посмеяться есть законнейшее стремление человеческой природы. Мы можем и должны давать этой потребности удовлетворение все более высокого художественного качества и в то же время сделать развлечение оружием коллективного воспитания, без педагогического опекунства, без назойливого направления на путь истины» [6, с. 187]. «Вождь народов» И.В. Сталин всерьез рассматривал кинематограф как один из возможных эф- 
фективных механизмов советской экономики, заявляя, «что можно было бы начать постепенное свертывание выпуска водки, вводя в дело вместо водки такие источники дохода, как радио и кино» [7, с. 312].

Эту же задачу преследовал всего несколько лет спустя и А. Гитлер, который, по мнению С. Никулина, едва получив власть, сразу же взялся «за эстетическую революцию» [3, с. 125]. Более того, фюрер всерьез решил, что это дело имеет не только внутрипартийный, но и важнейший общегосударственный характер, а потому поручил контроль за кинопроизводством непосредственно рейхсминистру народного просвещения и пропаганды Германии Й. Геббельсу, считавшему, именно в контексте кинематографа, что подлинная пропаганда - это чары, а не принуждение. Ее целью является сплочение общества и создание массовых идей, что представлялось ему настоящим искусством. Современное культурологическое исследование, предпринятое Р. Зухсландом в фильме «Голливуд Гитлера» (нем.: «Hitler's Hollywood», реж. R. Suchsland, «Eureka Entertainment», Германия, 105 мин., 2017 г. [8]), направлено на выявление сущностной связи прогресса кинематографа с историко-хронологической динамикой социального и политического заказа в Германии в $20-\mathrm{x}-40-\mathrm{x}$ гг. прошлого века. Анализируя поистине государственный подход к проблеме кинопроизводства в Третьем Рейхе, А. Свиридова, в своей статье в издании «Дискурс» указывает, что в Германии в «период между 1933-1945 гг. было снято около 1 тыс. фильмов» [9].

Исследователи Р. Манвиль и Х. Френкель, специально отмечают, что для самого Й. Геббельса кинематограф был вторым по эффективности после пропаганды инструментом власти, активно воздействующим на массы [10, р. 190]. Показательно, что интерес власти разных стран к управленческому, пропагандистскому и воспитательному потенциалу кино в Европе и мире в начале тридцатых годов был настолько мощным и устойчивым, что старейшие и наиболее значимые кинофестивали класса «А», и сегодня составляющие гордость мирового кинематографа, возникли именно в этот период. Так, в 1932 г. был впервые проведен Венецианский кинофестиваль, а в 1935 г. - Московский кинофестиваль.

На самом деле, кинематограф всецело оказался тем феноменом, который был непосредственно порожден соответствующим социокультурным контекстом и властным заказом. Ведь именно доминирующее в тот период мрачное и тревожное ощущение катастрофичности, которым ознаменовался рубеж XIX и XX вв., навсегда предопределило не только сюжетную и жанровую специфику этого вида искусства, но и обусловило характер уникальных художественных и технических приемов, направленных на максимально адекватное выражение господствующих корпоративных и общественных настроений, всякий раз проявляющихся в «мотивах насилия, тирании, рока, хаоса, покорности или заранее обреченного бунта» $[11$, с. 8$]$. Такого рода социальные и институциональные эманации неизменно и с максимальной точностью отражают саму природу кинематографа, изначально превращая тему ужаса в один их ведущих мотивов и сценариев формирования и массового продвижения киноиллюзии. 3. Кракауэр специально подчеркивал, что повсеместно используемые в европейских, советских и американских фильмах той поры «сцены насилия и животного страха - материал тем более кинематографичный» $[11$, с. 316]. А столь характерные для визуального ряда в кинолентах жанра ужасов приемы, такие как «движение масс, акты насилия, погони; и трактовка каждой из этих и подобных тем - всякий раз, по мнению исследователя, реализуются голливудскими создателями хоррор-продукции - с пониманием специфики кинематографа и со щедрым применением чисто кинематографической техники [11, с. 118]. 
Показательно, что именно насилие в кино («эластичный, скользящий, гибкий термин, который пересматривается и изменяется с течением истории или же в различных культурах» [12, с. 13]), как и смерть, ненависть к «ближнему» и «дальнему», изначально используется как наиболее выгодный фон и самый убедительный аргумент для формирования и продвижения идеологической модели как каждой отдельной кинокартины, так и государства в целом. И эту особенность мы наблюдаем не только на примере традиции тоталитарного кинематографа, для которого было крайне важным добиться монолитного сплочения масс абсолютно на любом ура-патриотическом, националшовинистическом или корпоративном основании. Вот как об этом замечательно рассказал Дж. Оруэлл на примере описания «двухминуток ненависти», которые ежедневно транслировались для всех членов партии в антиутопическом государстве Океания: «Словно от электрического разряда, нападали на все собрание гнусные корчи страха и мстительности, исступленное желание убивать, терзать, крушить лица молотом: люди гримасничали и вопили, превращались в сумасшедших. При этом ярость была абстрактной и ненацеленной, ее можно было повернуть в любую сторону, как пламя паяльной лампы» [13, с. 107]. В то же время, как это ни парадоксально, развлекательный Голливуд шагнул ещё гораздо дальше, превратив эту идею в особенный, удачно развивающийся и крайне прибыльный жанр, основанный на том, что именно ужасная смерть - это идея великого посмертного единения и уравнения во всемирном коллективе «родственников».

Для понимания жанровой и технической эволюции кинематографа очень важно проанализировать и социальную онтологию кино, а также ее непосредственную связь как с экзистенциальными запросами массового зрителя, так и с политикоидеологическим заказом власти. Пример такого анализа мы снова встречаем у 3. Кракауэра, авторитетно утверждавшего, что постоянно визуализируемые в пространстве кинематографа «стихийные бедствия, ужасы войны, акты насилия и террора, сексуальные сцены и смерть способны потрясти наше сознание. Во всяком случае такие сцены нас волнуют и возмущают, не позволяя нам оставаться на позиции стороннего наблюдателя. Поэтому ни от кого из очевидцев подобных событий, не говоря уже об активных участниках, нельзя ожидать точного рассказа о виденном. А поскольку грубые проявления человеческой природы или стихии являются элементом физической реальности, они тем более кинематографичны. Только кинокамера способна изобразить их без прикрас» [11, с. 90].

Именно это техническое средство позволяет максимально понять и неизменно воспроизводить стихийно сложившиеся принципы механистичного, инструментального типа мировосприятия, которое окончательно сформировалось в Европе только на рубеже Новейшего времени и сразу же потребовало адекватного способа визуализации. Фото- и кинокамеры бесстрастно отражают субъект-объектную модель коммуникации столь характерную для классической культуры, а также ревностно воспроизводят соответствующие ей стратегии властного управления. Монолог оператора с окружающим миром наиболее точно отражает общепринятые способы социальной стратификации и реализации принципов властного принуждения, исходящие из одного «светоносного» источника. А отдельно взятый кадр всегда является промежуточным результатом процесса препарирования субъектом части реальности, принудительно включенной в производственно-преобразующую практику конвейерного отражения мира.

Однако динамическая последовательность меняющихся кадров создает у зрителя стойкую иллюзию реальности того визуального, сенсорного и рационально структурированного опыта, который составляет пространство его цивилизованных представле- 
ний о самом себе и окружающем мире. Немецко-американский историк и теоретик искусства 30-60 гг. XX в. Э. Панофски, называвший подобный феномен «динамизацией пространства», специально указывал, что «в эстетическом плане он [зритель - aвm.] пребывает в постоянном движении, поскольку глаз его идентифицируется с объективом кинокамеры, которая постоянно перемещается в различных направлениях и меняет угол зрения. Пространство предстает зрителю в таком же движении, в каком пребывает он сам. В пространстве движутся не только твердые тела - движется само пространство: зыблется, растворяется, изменяется, снова сгущается» [14, с. 15].

В этом смысле именно кинематограф смог наиболее удачно визуализировать ту шокирующую систему катастрофичности и насилия, которая была столь характерна для этого периода, превратив его не только в ужасный документ эпохи, но и в предмет изысканного эстетического наслаждения. Уже к середине 20-х гг. XX в. среди исследователей кинематографа сформировалось мнение о том, что именно этот вид искусства в совокупности его художественных и технических возможностей провоцирует у зрителя состояния, во многом схожие с гипнозом и сновидением. Об этом же говорил и французский кинорежиссер, сценарист и продюсер, основоположник жанра музыкального фильма Р. Клэр, который при работе над фильмом «Антракт» (1924) впервые использовал прием, когда все, происходящее на экране, напоминало сон, выстроенный на основании ассоциаций. Этот эксперимент получил широкий резонанс у зрителей, а критики после случившегося и вовсе отнесли Р. Клэра к авангардистам дадаистского толка. 3. Кракауэр сходство фильма со сновидением объяснял тем, что кинокартина всегда погружает «зрителей в состояние дремотной мечтательности и, пожалуй [может aвm.], даже влиять на направление их грез» [11, с. 218]. Именно поэтому кинематограф столь быстро и уверенно превращался в массовое всемирное развлечение, поскольку постоянно стремился к явной или скрытой эксплуатации бессознательных желаний зрителя. Эту задачу с самого начала перед собой поставил и Голливуд, далеко не случайно во всем мире известный как «фабрика грез», ведь большая часть его продукции изначально была ориентирована на массового зрителя. Как раз в связи с этим 3. Кракауэр писал, что «между сюжетами подобных фильмов и мечтами, которые, повидимому, наиболее распространены среди кинозрителей, имеется некая взаимосвязь; иначе говоря, можно полагать, что события, изображаемые на экране, чем-то близки мечтаниям массового зрителя и поэтому способствуют его самоотождествлению с героями фильмов» [11, с. 219].

Последовательно разжигаемый кино зрительский вуайеризм позволяет всем и каждому пристально наблюдать за жизнью других, а популярный кинематограф со всей готовностью и любезностью постоянно предлагает массовому зрителю все то, чего тот изначально лишен в реальной жизни. Поэтому из «пресной», мрачной и трагически предсказуемой повседневности массовый потребитель с готовностью уходит в иллюзорный киномир беспрецедентных возможностей и головокружительных ощущений. И это обеспечивается не за счет рационально простроенных сюжетных схем. Наоборот, кинематограф предлагает набор специфических кодов, которые, минуя сознание, позволяют зрителю в кратчайшие сроки достигать желаемого. Именно поэтому кино является наиболее удачной формой непрерывной компенсации исключительной бедности эмоционально чувственного, событийного и коммуникативного мира обывателя. А в условиях нарастающих социальных рисков и опасностей кино и вовсе превращается в своеобразный тренинг формирования постоянной внутренней готовности к восприятию и избыточному потреблению ужасного. 3. Кракауэр отмечает в этой связи, что именно в процессе киносеансов «мы срываем с этих ужасов покровы нашего панического стра- 
ха и впечатлительного воображения, не позволявшего нам смотреть на них. Такой опыт освободителен, поскольку мы нарушаем весьма строгое табу» [11, с. 384]. Панибратски заигрывая с массовым зрителем, «кинокамера неожиданно разоблачает атрибуты его прежней жизни, лишая их смыслового значения, когда-то преображавшего их настолько, что они сами по себе не воспринимались, они были чем-то вроде скрытой электропроводки» [11, с. 90].

Парадоксально, то, что, с одной стороны, кинокамера как культурный символ эпохи посредством динамической визуализации позволяет выявить и представить актуальные внутренние проблемы индивида и коллективных способов его бытия. Но в то же время она сама является авторитарной формой презентации и реализации его внутреннего опыта, воплощенного в коммуникации активного и волеизъявляющего субъекта и пассивного, воспринимающего объекта. Камера в ее аналоговом или цифровом вариантах презентует базовые нерефлексивные принципы цивилизации, которая провозгласила насилие фундаментом социальной коммуникации и этатистских моделей ее оформления и презентации. Фактически снимающая, а затем и демонстрирующая камера является бесстрастным инструментом донесения до массового зрителя нерефлексивных способов формирования и отправления власти.

Именно поэтому сенсационная популярность всепоглощающего экранного насилия фиксирует возрастающую глубинную потребность общества в осознании тысячелетиями нерешаемых противоречий, которые человек сам же и породил. С помощью кино и жанра фильмов ужасов мы вот уже более чем столетие продолжаем совершенствовать тренинг по восприятию насилия в качестве естественного фона и базовой формы социальной коммуникации. Как раз это и объясняет небывалый коммерческий успех голливудских ужасных картин и их необыкновенную политическую ангажированность, которая становится все более значимым смыслом их существования. В этом смысле американский фильм ужасов (и колоссальный объем картин, снятых в этом жанре), безусловно, указывает на их возрастающий политико-идеологический подтекст, фиксирующий роковую трансформацию политики из сферы реализации осознанных целей посредством физического и психического принуждения в область откровенных и массовых манипуляций глубинными психофизиологическими процессами и социализированными рефлексами.

Но есть и вторая сторона проблемы, о которой также упоминал 3. Кракауэр, ведь визуализированный на экране кошмар создает условия для подготовки обывателя к постоянной возможной встрече и с реальным ужасом, а также к выработке в этой связи необходимых и желаемых для власти поведенческих реакций. Другими словами, в рамках этой модели предполагается формирование минимального возможного опыта осознания потенциальных рисков и угроз.

Вызывающе демократичная доступность кинопродукции для широкой и неподготовленной аудитории изначально превратила ее именно в феномен массовой культуры, бросивший реальный вызов «чистому искусству», ревностно обслуживавшему статусно-стратификационные запросы элиты, привыкшей к престижному потреблению мира, для которой теперь «уже сама реальность подстраивается под съемку» [8]. При этом формирующийся киноязык изначально и напрямую соответствовал запросам как раз широкой потребительской аудитории. 3. Кракауэр так охарактеризовал эту ситуацию: «Люди чувствовали себя опустошенными бессмысленной жаждой денег, <..> и погружались в то состояние духа, из которого родилось выражение Ламартина о предстоящей «революции презрения». <...> Пока ещё царила скука <...> [15, с. 112], «мучавшая буржуазное общество» $[15$, с.114]». «В наши дни не осталось практически ни- 
кого, кто не имел бы свободного времени. Контора уже не является местом постоянного пребывания, а воскресные выходные сделались непременным атрибутом жизни. Иными словами, у каждого есть возможность в прекрасные часы досуга подняться на вершину праведной скуки» [16], которая по мысли 3. Кракауэра и породила спецэффекты в кинематографе. Поэтому анализ интуитивно найденных создателями фильмов сюжетных схем и образных конструкций позволяет не только осознать изначальный потребительский запрос зрителя по отношению к популярным сюжетам и желаемым способам их технического оснащения, но также понять процесс идентификации киножанра в художественном и социокультурном пространстве.

Так, легендарный Мари-Жорж-Жан Мельес - один из основоположников мирового кинематографа, снявший с 1896 по 1913 г. более пятисот кинокартин, - достаточно быстро пришел к выводу, что кинематограф является не только актуальным и современным видом искусства, но и крайне эффективным в экономическом смысле производством. Поэтому он посчитал необходимым повсеместное использование спецэффектов для привлечения и удержания внимания массового зрителя, что сразу сделало его фильмы успешным коммерческим проектом. По мнению специалистов, «между 1888 и 1907 годом Мельес изобрел тридцать новых фокусов, часть из которых потом была перенесена на экран» $[17$, p. 76$]$. В топе спецэффектов, столь удачно апробированных Мельесом, на первом месте было таинственное и загадочное превращение предметов и объектов, например мистическая и шокирующая трансформация омнибуса в катафалк.

Поскольку многие режиссеры той поры были напрямую связаны с крайне демократичным цирковым искусством, то совершенно неудивительно, что вторым по значимости заимствованным и трансформированным в кино эффектом были иллюзии, изначально характерные для цирковой арены, позволявшие фокусникам достигать поистине мистической власти над зрительской аудиторией. Именно цирковые иллюзии послужили основой формирования и апробирования набора кинематографических спецэффектов, вооружившись которыми кинофильмы - «истории, которые ты смотришь с открытыми глазами» $[18$, с. 57] - успешно покоряли умы и сердца столь различных по социальному, национальному и интеллектуальному потенциалу зрителей во всех уголках мира.

Кроме этого, в формировании первых спецэффектов в кино широко использовался опыт театра, за плечами которого были столетия успешной апробации приемов актерско-игрового, литературного, декораторского, технического, осветительного, звукового оформления и сопровождения сценического искусства, а также оценки их воздействия на различные зрительские аудитории. Наиболее близким и родственным кино жанром искусства стала и только что возникшая фотография, во многом заимствовавшая колоссальный опыт классической пейзажной и портретной живописи, композиции, колористики, светотени и т. д., в которой «пространство вокруг предмета и есть его смысл» [19]. Ведь как раз такой опыт и позволил в будущем сформировать представления о требованиях и критериях построения кадра и эпизода как неотъемлемых элементов единого динамического полотна кинофильма, приобретающего необычайную власть над умами и сердцами зрителей, заставляющих их видеть именно то и именно в таком ракурсе, как задумано режиссерами и операторами кинокартин. Во многом поэтому, признавая колоссальное значение изначального видения будущего фильма еще до начала съемок, в числе главных авторов кинокартин и до сих пор прежде всего упоминаются фамилии режиссеров и операторов. А необходимость учета постоянного и непрерывно увеличивающегося запроса зрительской аудитории на спецэффекты во многом предопределила и характер номенклатуры авторов кинофильмов, упоминаемых в титрах кроме них. 
В первую очередь это технические специалисты, обеспечивающие полноценный производственный процесс - от написания сценария до демонстрации фильма в кинотеатрах и на миллионах домашних экранов. В этом смысле уже первые удачные находки немого кино на протяжении XX в. лишь развиваются, получая со временем подлинный размах. И если в пору появления кинематографа спецэффекты были призваны так или иначе украсить визуализацию сюжета, то уже в самом начале XXI в. производство спецэффектов превратилось в особую и достаточно привилегированную отрасль, без которой современная киноиндустрия вообще немыслима. Спецэффект стал ведущим средством презентации смысла, а в некоторых случаях и вообще единственным смыслом фильма, всецело повелевающим чувствами, умами, сердцами, настроениями и поведением миллионов зрителей по всему миру. В условиях предельной схематизации и минимизации самого сюжета современных кинокартин спецэффекты фактически вытеснили традиционную литературную канву сценария, связанную со смысловым оформлением ключевых линий сюжета, заместив их фантасмагоричным калейдоскопом технологично обработанных и непрерывно извергающихся динамичных образов. Закономерное завоевание спецэффектом «командных высот» в кинобизнесе и медиасреде стало отражением принципиально изменившихся социокультурных запросов общества миллениалов, которые в полном соответствии с революционными традициями XX в. продолжали буквально фонтанировать негативно-нигилистическими эмоциями разочарования характером сложившихся в обществе потребительских идеалов, а также социально-политическими практиками их презентации и реализации. Ведь как раз посредством кинематографических спецэффектов у молодежи формируется латентная форма протеста-избегания наличной реальности как способ альтернативного полагания и продвижения новых идеалов гиперреальности.

Кинематограф в подобной стратегии закрепления спецэффекта превращается в пространство непрерывной и шокирующей сенсации. В силу этого зрительское восприятие трагически утрачивает естественную способность привязываться к реальным процессам, происходящим в окружающем мире. В связи с этим нарушается сама психофизиология формирования и трансляции представления. В итоге, разрушив вековую оппозицию реального и иллюзорного, нейтрализовав шок от их извечного конфликта, кино, само того не подозревая, подготовило для власти не только новый формат управленческого пространства, но взрастило и новую генерацию самих подданных, готовых бесконфликтно воспринимать свое постоянное нахождение в иллюзорном, искусственном пространстве, которое во многом является тождественным пространству власти. Создавая и транслируя на протяжении тысячелетий развития цивилизации неестественные, основанные на принуждении, формы коммуникации между людьми, власть в самом факте появления кинематографа и его невероятных технических возможностей получила надежного союзника и проводника своей воли в необычайно привлекательной, волнующей форме. Во многом это обусловило утрату способности адекватно воспринимать окружающий мир, а при обилии визуального материала фактически привело в утрате зрителем способности различения, которая, по мнению П. Вирилио, обернулась повсеместной слепотой. В связи с чем, он указывал, что в «структуру грядущей «машины зрения» заложена слепота. Что такое производство видения без взгляда, если не воспроизводство интенсивного ослепления? Ослепления, являющегося сутью новой, заключительной формы индустриализации - индустриализации не-взгляда» [20, с. 132]. Фактически кинематограф его и увлечение техническими приемами формирования гиперреальности становится причиной формирования столь неоднозначной ситуации, о которой нас предупреждает Вирилио. 
Получается, что в условиях повсеместной зрительской «слепоты» только спецэффекты могут зафиксировать внимание обывателя на происходящих на экране событиях. Именно в подобном контексте спецэффекты сформировались как совокупность кинематографических приемов, которые позволяют создать киноиллюзию, полноценно замещающую наличную реальность. Поскольку речь идет как минимум о ее удвоении и создании такой визуальной среды, которая лишь частично воспроизводит облики повседневности, то кинематографу уже с самого начала своего становления необходимо было определиться с желаемым содержанием вторичной реальности, а также с технологией ее производства и набором наиболее приемлемых технических приемов ее оснащения. Если же вести речь о содержании гиперреальности, то кино пошло по традиционному пути, уже не единожды пройденному жанрами классического искусства, заслужившими наибольший интерес у представителей власти.

Художественный опыт Средневековья, и в особенности Возрождения и Нового времени, подтверждает, что европейская культура, находясь в определенных кризисных состояниях, неизменно возвращается к античному наследию, высокие достижения которого всегда обеспечивались образно-символическим потенциалом действующих мифологических парадигм. Всякий раз активно вовлекаемые в культурный оборот (особенно в экстремальные периоды развития) персонажи «низкой» и «высокой» античной мифологии на века вперед стали надежной символической «палочкойвыручалочкой» для европейского искусства, которое периодически оказывалось нечувствительным к фундаментальным природным и антропологическим смыслам.

Вся уникальность ситуации начала XX в. состояла в том, что в этот раз Европа всерьез столкнулась с настоящим и всесторонним кризисом, связанным с накопившейся вековой «усталостью» культуры в отношении перманентно и достаточно агрессивно навязываемых властью, религией и философией «позитивных», «восходящих» стратегий индивидуального и социального развития, которые в таких условиях достаточно легко трансформируются в свою полную противоположность. А потому вместо столь желанного прогрессивного и повседневного подъема культуры и социума XX в. стал эпохой масштабных, поистине всепланетных вооруженных конфликтов, противоречивых революционных экспериментов, сциентистского натиска на природу и человека, уничижающих и уничтожающих технологий, впервые поставивших не только каждого человека в отдельности, но все человечество на грань физического выживания.

Совершенно не удивительно, что кинематограф, появившийся в этой пучине, активно заимствует именно потенциал «низовых» мифологий для создания и продвижения своего идеологически ориентированного художественного продукта. Поэтому в той гиперререальности, которую конструирует и продвигает как мировой, так и собственно голливудский кинематограф, как раз насилие, страх и смерть изначально являются основными действующими персонажами. Именно эти подлинные, а не произвольно назначенные номенклатурные «герои нашего времени» навсегда становятся образносимволическим фундаментом художественного многообразия и технических приемов визуализации новой искусственной реальности, активно производимой и продвигаемой голливудской «фабрикой грез».

Как уже отмечалось, мировой и особенно голливудский кинематограф со временем все более тяготеет к «освобождению» от изысканных витиеватостей сюжета и описания сложных психологических противоречий, на преодоление которых направлен фильм. Вместо этого мы наблюдаем процесс неуклонного и окончательного завоевания спецэффектом всего темпорального и пространственного наполнения кинокартины. Традиционно спецэффекты в кино воспроизводят гиперреальность двух видов. В пер- 
вом случае мы имеем дело с ее эвдемонической, конструктивной разновидностью (комедии, мелодрамы, исторические и приключенческие фильмы), в рамках которой она изображается в условно-позитивной или же нейтрально-фоновой функциональности. Поэтому используемые спецэффекты, как правило, направлены на воспроизводство и визуальное сопровождение модели достижимого и близкого «счастья», организованного, направляемого и патронируемого действующими моделями социального управления, которые непосредственно соответствуют «прогрессивной» природе человека. Что касается второй модели, которую, по нашему мнению, условно можно назвать танатологической, то в ней настойчиво воспроизводятся сценарии гиперреальности, основанной на демонстративном педалировании сюжетов, связанных с властным обеспечением безопасности и визуализации комплекса угроз, проистекающих от ее недостатка или же полного отсутствия. Сюда можно отнести детективы, боевики, фантастику, фильмыкатастрофы, нуар, триллеры и фильмы ужасов и др., каждый из которых по-своему раскрывает механизм властного шантажа безопасностью в отношении как отдельного индивида и социальных групп, так и общества в целом.

Подробнее проанализируем, в чем состоят особенности формирования и действия спецэффектов в рамках второй модели гиперреальности. Первой и главной чертой, которая отличает эту группу голливудских ужасных кинотекстов, является повсеместное использование визуальных метаморфоз, иллюстрирующих эскалацию потенциальных опасностей и угроз, связанных с внезапным превращением реального в нереальное. Как правило, природные ландшафты, объекты, персонажи и предметы, изображаемые в американских фильмах ужасов, демонстрируют зрителям как минимум два своих «агрегатных» состояния. Причем исходное традиционно связывается с привычным и будничным контекстом коммуникации, тогда как второе рельефно демонстрирует новое, «добавленное» качество киноперсонажа: добрый - злой, обычный - героический, живой - мертвый, естественный - сверхъестественный, человеческий - божественный, человеческий - животный и т. д.

Вторая черта голливудских «ужасных» спецэффектов состоит в том, что они должны обеспечивать полномасштабное погружение героев и зрителей в аффективное состояние гормонального шока. Решение этой задачи предполагает использование таких визуальных и звуковых средств, которые на бессознательном уровне должны сигнализировать о наличии крайней формы опасности и демонстрировать типичные модели поведения человека, попавшего в подобные экстремальные условия.

Третья черта спецэффектов в фильмах ужасов - это подчеркнутая порнографичность изображений, в рамках которой сцены насилия и убийств демонстрируются с максимальным оптическим приближением, создающим иллюзию «развороченного» или принудительно и жестоко «вскрытого» предмета. Ж. Бодрийяр в книге «Соблазн» пишет о порнографии так: «Она не какая-нибудь идеология, т. е. не прячет никакой истины, - она симулякр, т. е. эффект истины, прячущий только то, что никакой скрытой истины не существует» [21, с. 80]. И если сам французский философ упоминал о порнографии в связи с особыми киноперверзиями, то в контексте голливудских фильмов ужасов можно констатировать формирование глобальной установки на порнографическую визуализацию гиперреальности страданий и смерти, представленной в крайне избыточном оптическом вуайеризме раскроенной человеческой плоти и изуродованных предметов вообще. Поэтому используемые в этих случаях спецэффекты должны быть направлены на демонстрацию таких предметных атрибутов, которые оказываются недоступными в повседневности и явно указывают на нереальность происходящего. 
Четвертая черта спецэффектов состоит в предельной инструментализации всех мыслимых и немыслимых сценариев коммуникации живых и неживых предметов. Даже самые заурядные инструменты, парадоксальным образом используемые как орудия пыток и смерти, должны быть продемонстрированы зрителю в их предельной активной функциональности, чудовищной самодеятельной анимичности, повсеместно сеющей смерть и страдания. Именно так, в процессе киноэксплуатации, инструменты обязательно витализируются, приобретают автономное бытие и субъектность, особенно заметные на фоне мертвенно-пассивных обывателей. При этом все отдельно взятые спецэффекты умышленно «играют» друг на друга, многократно возгоняя эмоциональные аффекты, аккумулируя и усиливая их ужасающий потенциал.

Пятая черта спецэффекта заключается в реализации в отношении зрителей необычайных гипнотических возможностей жанра киноужаса, которые всецело направлены на достижение эффекта «отключения» сознания, обеспечивая максимальную вовлеченность публики в кровавое повествование и ее эмпатию по отношению к происходящему ужасу.

Шестой чертой является саспенс-эффект, в рамках которого атмосфера неуклонно нарастающей тревоги должна непременно сменяться шоком: «“саспенс” заменяет “шок”» [22, с. 478]. Соответственно, спецэффект должен быть направлен на демонстрацию максимального разрыва всего наблюдаемого зрителем на экране с привычными для него повседневными образами.

Седьмой чертой спецэффекта выступает создание и эскалация ощущений беспорядка и хаоса, которые в новой реальности являются симулякрами стабильности. Показательно, что этот прием оказывается наиболее востребованным с точки зрения системы социального управления, поскольку на самом деле власть не столько не пытается восстановить статус-кво, но и всячески (явно или скрыто) лоббирует хаос как новую форму постцивилизованного порядка. А это значит, что именно ужасный спецэффект выступает базовым социальным запросом власти, обеспечивающим визуализацию ее скрытых манипулятивных механизмов.

Восьмая черта касается формирования и закрепления у зрителя особой модели сенсорной нестабильности и депривации, которая на основе шокирующих спецэффектов должна создавать и поддерживать у него стойкое ощущение пустоты, ненужности и принципиальной невозможности сознания в условиях непрерывно чередующихся аффективно-амнезийных конвульсий.

Девятая черта спецэффектов связана с особенностями демонстрации агрессивности экранного предмета, который выражает особенности стратегии коммуникации, исходящей от принуждающего субъекта. Подобные образы не только позволяют закрепить базовую политическую стратегию власти, но и сформировать у зрителя бессознательное ощущение обыденности и рядоположенности того ужаса, который происходит на экране.

Десятая черта предполагает непосредственное воздействие спецэффектов на поведение обывателя, которое может осуществляться в двух вариантах. Во-первых, зритель, окончательно шокированный агрессией предметов, многократно усиленной спецэффектами, может поддаться панике и признать свое поражение в ужасном состязании с экранным злом. Во-вторых, он может бессознательно отождествиться с агрессивными предметами или же персонажами, орудующими ими, и воспринять их модель властвования как пример для подражания и прямую провокацию к проявлению собственной агрессии. В любом случае оба описанных сценария представляют собой две стороны одной манипулятивной «медали», с помощью которой власть держит потребителя ви- 
зуальной голливудской агрессии, проявляющейся в виде спецэффектов, на «коротком поводке» страха. Постоянная демонстрация такого рода агрессии, доказывает, что спецэффекты направлены на формирования и последующего тренинга хоррор-габитуса постоянно испуганного и всегда готового к бегству обывателя.

Одиннадиатая черта спецэффекта состоит в том, что он обязательно должен содержать идеологизированный социокультурный код как основной инструмент визуальных манипуляций власти, красочно и привлекательно воспроизводящий принципы бессознательного управления публикой. Таким образом, в результате повсеместного использования спецэффектов происходит глобальная сенсорная подмена, в рамках которой любая второстепенная, несущественная деталь может быть представлена в качестве главного, а то и единственного носителя смысла путем гипертрофированности образа, формы, цвета и звука. В равной степени любой существенный элемент может быть произвольно (умышленно) вытеснен на второй план, заретуширован или же не продемонстрирован вовсе. В такой логике спецэффект является визуализированной формой замещения истины ложью.

Двенадиатая черта спецэффекта заключается в его способности отсылать зрителя к индивидуальному опыту нуминозных, сакральных переживаний архетипического, которые в зависимости от категорий коллективного опыта сообразно представлены чередой ужасных демонстраций трагической утраты тела, чувств, понимания, отношения к себе самому и к другим и потери осознания вписанности в темпоральный поток «прошлое-настоящее-будущее».

Тринадиатая черта спецэффекта состоит в его способности внушать зрителю иллюзию собственной принадлежности к коллективу (движимому проверенными временем установками и традициями), которая визуально презентуется в сценах массовых действий.

Четырнадиатая черта спецэффекта связана с его структурой, представленной набором элементов, соединяемых в визуальное целое посредством монтажа и указывающих на иллюзорность любого сконструированного пространства, предмета, отношения или состояния.

Пятнадцатая черта спецэффекта заключается в том, что его базовым элементом является технология кадрирования реальности, позволяющая власти произвольно управлять ей с помощью фрагментирования как самих процессов, так и сценариев их восприятия, а также последующего монтажа гиперреальности с помощью пересборки предварительно раскадрованных фрагментов исходной реальности. В этой логике находились рассуждения К. Тарантино, который, монтируя фильм «Доказательство смерти», констатировал: «Я был жестокий американский тоталитарный кинодистрибьютор, который сокращает фильм до точки, в которой начинает отсутствовать связность. Я обрезал его до костей, удалив весь жир, чтобы посмотреть, сможет ли он после этого существовать, и это сработало» [23, с. 181]. Собственно, принудительно изолированный кадр и становится визуальным, кинематографическим символом власти, воспроизводя в каждом отдельном фрагменте схему властного препарирования реальности. Однако, в зависимости от жанра, каждый такой кадр может быть либо свидетельством величия власти и безусловной справедливости ее решений, либо же визуализацией грозного предупреждения о том, что может произойти с каждыми индивидом и обществом в целом в случае неподчинения или сопротивления властным действиям. Поэтому каждый кадр сам по себе - это уже зафиксированный и идеологически позиционированный эпизод хроники власти. В то же время подобные кадры, будучи объединенными в последовательности, повествуют в легендарной форме о достижениях либо неудачах 
коммуникации власти и общества. Поэтому каждый фильм, в зависимости от жанра, представляет собой лишь визуализацию «темной» или же «светлой» мифологии власти. В этом смысле голливудский фильм ужасов представляет собой либо кошмарное предупреждение подвластному пространству о том, что с ним может быть в случае конфликта с властью, либо же (в зависимости от степени ужаса) демонстрирует неприкрытый визуальный шантаж возможными последствиями полной анархии. Подобная технология онтологизирует как сам спецэффект и гиперреальность, создаваемую с его помощью, так и любые возможные политико-идеологические сценарии ее трактовки.

Подводя промежуточные итоги первичного изучения причин возникновения спецэффектов и стратегий их властно-идеологического использования в мировом и собственно американском «ужасном» кинематографе, следует сказать, что прогресс в кино только лишь с одной стороны был напрямую связан с теми техническими приемами, которые использовались в различных сферах искусства, науки и производства. Но только явно или неявно сформулированный в отношении кинематографа политикопропагандистский заказ на такого рода иллюзии трансформируют сакральные и нуминозные ожидания зрительских масс в новую форму политического принуждения, целенаправленно выведенного за рамки классических, рационализированных политических схем и методик. В результате политика на уровне спецэффекта перестает быть политикой в классическом понимании (формой осознанной реализации властного принуждения субъекта по отношению к объекту). Специальные приемы в кинематографе являются специфическим культурным кодом, с лихвой компенсирующим ущербность односторонних, рационализированных схем управления, дополняющим их рычагом глубинного воздействия и оперирования архетипическими матрицами, которые непосредственно отсылают к сакральному и нуминозному опыту цивилизации, представляют наиболее воспринимаемый и усваиваемый горизонт индивидуальных и массовых ожиданий.

Изучение инструментальных возможностей кинематографа как формы визуального миссионерства власти, эдакой массовой «проповеди спасения», которое она несет заблудшим или ещё не ставшим на цивилизованный путь индивидам и их сообществам, а также особенностей их реализации в американских фильмах ужасов является достаточно актуальной проблемой. Именно на основании исследования такой модели кинематографа мы получаем возможность детального феноменологического анализа не только стратегий формирования и отправления политической власти, но и социальноантропологической сущности всей цивилизации. Это позволяет нам определить цивилизационно-коллективную модель бытия человека исключительно как форму садомазохистского отношения к окружающему миру. В таком контексте все участники коммуникации рассматриваются как носители исключительной потенциальной взаимной угрозы, а единственный ее смысл оказывается редуцированным к биотическим установками борьбы за выживание. По сути, голливудское кино вообще, и фильм ужасов в частности являются схемой визуальной девитализации Homo sapiens и одним из действенных способов доктринального обоснования хоррологии цивилизации посредством выстраивания «кратологических практик на основе сублимации физиологических нужд и биотических рисков человека в стратегии и тактиках социального управления» $[24$, c. 70$]$. Однако именно на основании исследования деструктивности киноонтологии цивилизации впервые предоставляется возможность установления потенциальных внецивилизационных форм бытия человека и его сознания.

Исследование выполнено при финансовой поддержке РФФИ в рамках научного проекта № 18-011-00129. 


\section{СПИСОК ЛИТЕРАТУРЫ}

1. Люмет С. Как делается кино. - М.: Манн, Иванов и Фербер, 2018. - 256 с.

2. New keywords: a revised vocabulary of culture and society / Eds. T. Bennett, L. Grossberg, M. Morris. Oxford: Blackwell Publishing Ltd., 2005. - 425 p.

3. Никулин Н. От братьев Люмьер до голливудских блокбастеров. Главное в истории кинематограф. М.: Эксмо, 2020. - 320 с.

4. Ленин В.И. ПСС. - М.: ИПЛ, 1970. - Т. 44. - 725 с.

5. Болтянский Г. Ленин и кино. - М.; Л.: Гос. изд-во, 1925. -88 с.

6. Троцкий Л.Д. Водка, церковь и кинематограф // Киноведческие записки. - 2000. - № 45. - С. $185-188$.

7. Сталин И.В. Политический отчет Центрального комитета XV Съезду ВКП(б). 3 декабря 1927 г. // Сочинения в 16 т. Т. 10. - М.: ОГИЗ: Государственное издательство политической литературы, 1949. - 396 c.

8. Голливуд Гитлера // Dok-film.net. URL: https://dok-film.net/gollivud-gitlera-hitlers-hollywood-2018.html (дата обращения 03.08.2020).

9. Свиридова А. «Голливуд Гитлера»: кино Третьего рейха // Дискурс. URL: https://discours.io/articles/culture/gollivud-gitlera-kino-tretego-reyha (дата обращения 03.08.2020)

10. Manvell R., Fraenkel H. Doctor Goebbels: his life and death. - New York: Skyhorse, 2010. - 360 p.

11. Кракауэр 3. Природа фильма. Реабилитация физической реальности. - М.: Искусство, 1974. - 424 с.

12. Kendrick F. Film violence: history, ideology, genre. - London; New York: Wallflower, 2009. - 144 p.

13. Оруэлл Дж. Скотный двор. 1984. Памяти Каталонии. Эссе. - М.: Пушкинская библиотека: АСТ, 2003. - $661 \mathrm{c}$.

14. Кракауэр 3. От Калигари до Гитлера. Психологическая история немецкого кино. - М.: Искусство, 1977. - $320 \mathrm{c}$

15. Кракауэр 3. Жак Оффенбах и Париж его времени. - М.: Аграф, 2000. - 416 с.

16. Иванов А. Скука и масса у Зигфрида Кракауэра. URL: https://admarginem.ru/2020/05/29/zigfridkrakauer-skuka/ (дата обращения 03.08.2020).

17. Severine W., Duval G. A trip to the moon back in color (La Couleur Retrouvee du Voyage dans la Lune). Nanterre: Groupama Gan Foundation for Cinema, 2011. - 196 p.

18. Martínez M.J.F. Literature and cinema. History of a fascination // Revista de Medicina y Cine. - 2005. V. 1. - № 3. - P. 57-59.

19. Кракауэр 3. Орнамент массы. Веймарские эссе. URL: https://www.litres.ru/zigfrid-krakauer/ornamentmassy-veymarskie-esse/chitat-onlayn/page-2/ (дата обращения 03.08.2020)

20. Вирилио П. Машина зрения. - СПб.: Наука, 2004. - 138 с.

21. Бодрийяр Ж. Соблазн. - М.: Ad Marginem, 2000. - 317 с.

22. Делез Ж. Кино. - М.: Ad Marginem, 2004. - 623 с.

23. Шон Т. Тарантино. От криминального до омерзительного: все грани режиссера. - М.: Эксмо, 2019. $256 \mathrm{c}$.

24. Маленко С.А., Некита А.Г. Биотизация образа жизни обывателя в идеологической традиции американского фильма ужасов // Векторы благополучия: экономика и социум. - 2019. - № 4 (35). C. 63-73. URL: http://earchive.tpu.ru/handle/11683/57843?locale=en (дата обращения 10.08.2020).

Поступила 15.08.2020 г. 
UDC 316.772.5:316.462:791.321.9(73)

\title{
POWER-SPECIAL EFFECT: THE GENESIS AND POLITICAL AND IDEOLOGICAL MISSION OF VISUAL TECHNOLOGIES IN THE TRADITION OF AMERICAN HORROR FILM
}

\author{
Sergey A. Malenko, \\ olenia@mail.ru \\ Andrey G. Nekita, \\ beresten@mail.ru \\ Yaroslav-the-Wise Novgorod State University, \\ 41, B. St. Petersburgskaya street, Veliky Novgorod, 173003, Russia.
}

Sergey A. Malenko, Dr. Sc., professor, head of the Department of philosophy, cultural studies and sociology, Yaroslav-the-Wise Novgorod State University.

Andrey G. Nekita, Dr. Sc., professor, Yaroslav-the-Wise Novgorod State University.

Relevance. Establishing the dependence of the nomenclature and nature of artistic and technical techniques used in cinema on the socio-cultural and political-ideological context is a significant scientific problem and allows us to form a new, interdisciplinary subject field in modern cultural studies. The aim of the research is to analyze the direction of the evolution of the visual and political essence of cinematic special effects in the context of historical and cultural transformations of Western society in the late XIX - early XXI centuries, as well as the features of their use in the tradition of American horror films. Methods. The article uses a number of methods that allow carrying out the comparative, semiotic and psychoanalytic analysis of the essence and artistic practice of using special effects in Hollywood cinema. Results. The formation of the artistic practice of American horror films is directly related to the use of technical methods that allow you to keep constant audience interest in this film production. Special effects in various film genres are the result of rethinking the experience of circus, theater and photo art in constructing a thanatological hyperreality that displaces images of the objective world and replaces them with dynamic illusions. A sharp escalation in the use of these techniques indicates the emergence of new instrumental opportunities for creating and promoting secondary reality. And the ever-widening gap between the real and the cinematic world demonstrates the growing alienation of the public from traditional forms of social practice, which causes a jump in simulation experiments in horror films and an increasing interest of the authorities in visual ways of attracting, retaining and unconsciously controlling the attention and behavior of the mass audience. Findings. The range of cinematic special effects creates a visual technology for managing fear, forms a special horror habit, which is a commercially profitable and most popular political and ideological task of a Hollywood horror film.

Key words: American horror films, power-special effect, horror-habitus, hyperreality, simulation, visualization, mass culture.

The reported study was funded by RFBR according to the research project no. 18-011-00129.

\section{REFERENCES}

1. Lyumet S. Kak delaetsya kino [How movies are made]. Moscow, Mann, Ivanov i Ferber Publ., 2018. 256 p.

2. New keywords: a revised vocabulary of culture and society. Eds. T. Bennett, L. Grossberg, M. Morris. Oxford, Blackwell Publishing Ltd., 2005. 425 p. 
3. Nikulin N. Ot bratev Lyumer do gollivudskikh blokbasterov. Glavnoe v istorii kinematografa [From the Lumiere brothers to Hollywood blockbusters. The main thing in history is cinema]. Moscow, Eksmo Publ., 2020. 320 p.

4. Lenin V.I. PSS [Complete Works]. Moscow, Political Literature Publ. House, 1970. Vol. 44. 725 p.

5. Boltyanskiy G. Lenin i kino [Lenin and the cinema]. Moscow, Leningrad, Gos. izd-vo Publ., 1925. 88 p.

6. Troczkiy L.D. Vodka, tserkov i kinematograf [Vodka, church and cinema]. Kinovedcheskie zapiski, 2000, no. 5, pp. 185-188.

7. Stalin I.V. Politicheskiy otchet Tsentralnogo komiteta XV Sezdu VKP(b). 3 dekabrya 1927 g. [Political report of the Central Committee to the XV Congress of the CPSU (b). December 3, 1927]. Moscow, OGIZ Publ., Gosudarstvennoe izdatelstvo politicheskoy literatury Publ., 1949. 396 p.

8. Gollivud Gitlera [Hitler's Hollywood]. Dok-film.net. Available at: https://dok-film.net/gollivud-gitlerahitlers-hollywood-2018.html (accessed 14 July 2020).

9. Sviridova A. «Gollivud Gitlera»: kino Tretego reykha [«Hitler's Hollywood»: cinema of the Third Reich]. Diskurs. Available at: https://discours.io/articles/culture/gollivud-gitlera-kino-tretego-reyha (accessed 18 July 2020).

10. Manvell R., Fraenkel H. Doctor Goebbels: his life and death. New York, Skyhorse Publ., 2010. 360 p.

11. Krakauer Z. Priroda filma. Reabilitatsiya fizicheskoy realnosti [The nature of the film. Rehabilitation of physical reality]. Moscow, Iskusstvo Publ., 1974. 424 p.

12. Kendrick F. Film violence: history, ideology, genre. London; New York, Wallflower Publ., 2009. 144 p.

13. Oruell Dzh. Skotny dvor. 1984. Pamyati Katalonii. Esse [Animal farm. 1984. Memory of Catalonia. Essays]. Moscow, Pushkinskaya biblioteka Publ., AST Publ., 2003. 661 p.

14. Krakauer Z. Ot Kaligari do Gitlera. Psikhologicheskaya istoriya nemetskogo kino [From Caligari to Hitler. Psychological history of German cinema]. Moscow, Iskusstvo Publ., 1977. 320 p.

15. Krakauer Z. Zhak Offenbakh i Parizh ego vremeni [Jacques Offenbach Krakauer Z. Jacques Offenbach and the Paris of his time]. Moscow, Agraf Publ., 2000. 416 p.

16. Ivanov A. Skuka i massa u Zigfrida Krakauera [Boredom and mass in Siegfried Krakauer]. Available at: https://admarginem.ru/2020/05/29/zigfrid-krakauer-skuka/ (accessed 18 July 2020).

17. Severine W., Duval G. A trip to the moon back in color (La Couleur Retrouvee du Voyage dans la Lune). Nanterre, Groupama Gan Foundation for Cinema, 2011. 196 p.

18. Martínez M.J.F. Literature and cinema. History of a fascination. Revista de Medicina y Cine, 2005, vol. 1, no 3, pp. 57-59.

19. Krakauer Z. Ornament massy. Veymarskie esse [Mass ornament. Weimar essays]. Moscow, Ad Marginem Press, 2019. 360 p. Available at: https://www.litres.ru/zigfrid-krakauer/ornament-massy-veymarskieesse/chitat-onlayn/page-2/ (accessed 25 July 2020).

20. Virilio P. Mashina zreniya [Vision machine]. St. Petersburg, Nauka Publ., 2004. 138 p.

21. Bodriyar Zh. Soblazn [Temptation]. Moscow, Ad Marginem Publ., 2000. 317 p.

22. Delez Zh. Kino [Cinema]. Moscow, Ad Marginem Publ., 2004. 623 p.

23. Shon T. Tarantino. Ot kriminalnogo do omerzitelnogo: vse grani rezhissera [Tarantino. From the criminal to the disgusting: all facets of the director]. Moscow, Eksmo Publ., 2019. 256 p.

24. Malenko S.A., Nekita A.G. Biotizatsiya obraza zhizni obyvatelya v ideologicheskoy traditsii amerikanskogo filma uzhasov [Biologization of lifestyle of the inhabitant in the ideological tradition of american horror film]. Journal of wellbeing technologies, 2019, no. 4 (35), pp. 63-73. Available at: http://earchive.tpu.ru/handle/11683/57843?locale=en (accessed 10 August 2020).

Received: 15 August 2020. 